JKM (Jurnal Kebidanan Malahayati),Vol 7,No.4.Oktober 2021,

ISSN (Print) 2476-8944 ISSN (Online) 2579-762X, Hal 697-703

\title{
JUS MENTIMUN DAPAT MENURUNKAN TEKANAN DARAH PADA WANITA MENOPAUSE
}

\author{
Fika Kusmawati ${ }^{1}$, Sri Dinengsih ${ }^{2}$, Risza Choirunisa ${ }^{3}$ \\ ${ }^{123 K e b i d a n a n, ~ U n i v e r s i t a s ~ N a s i o n a l ~ J I n ~ R M ~ H a r s o n o ~ n o ~} 1$ Jakarta Selatan \\ Email : fikakusmawati1@gmail.com, risza.choirunissa@gmail.com \\ *Korespondensi email dini_alba@yahoo.com
}

\section{ABSTRACT CUCUMBER JUICE CAN LOWER BLOOD PRESSURE IN MENOPAUSAL WOMEN}

Background: The prevalence of hypertension in Indonesia is $45.9 \%$ for $55-64$ years old, $57.6 \%$ for $65-74$ years old and $63.8 \%$ for $>75$ years old. It is estimated that people with hypertension in Indonesia reach 15 million people but only $4 \%$ are controlled hypertension. The prevalence is $6-15 \%$ in the elderly, $50 \%$ are not aware of being hypertensive patients, so they tend to become severe hypertension because they do not avoid and do not know the risk factors and $90 \%$ are essential hypertension.

The Purpose Knowing the effect of giving cucumber juice on blood pressure in postmenopausal women in the work area of the Puskesmas baktijaya, south tangerang city in 2021 in the intervention group and control group.

Methodology: The researcher used a quasi-experimental research design with a pre-test and with control design. The sample in this study amounted to 36 people consisting of 18 intervention groups and 18 control groups. The sampling technique used was purposive sampling. The research instrument consisted of an observation sheet on the state of blood pressure in patients with hypertension before being given cucumber juice and changes in blood pressure in postmenopausal women with hypertension after being given cucumber juice.

Research result: There was an effect of giving cucumber juice on decreasing blood pressure in the intervention group with a mean rank of 13.72 and in the control group with a mean rank of 23.28. With a $p$ value of $0.005<0.05$. There is an effect of giving cucumber juice to decrease diastolic blood pressure in the intervention group with a mean rank of 23.94 and in the control group with a mean rank of 13.06. With a $p$ value of $0.001<0.05$.

Conclusions and suggestions: Giving cucumber juice can affect the reduction of blood pressure in postmenopausal women. regularly.

Suggestion giving cucumber juice to menopausal women or the public can be applied and consumed Keywords:Menopausal Women, Hypertension, Cucumber

\section{ABSTRAK}

Latar Belakang: Prevalensi hipertensi di Indonesia sebesar 45,9\% untuk umur 55-64 tahun, 57,6\% umur 65-74 tahun dan 63,8\% umur $>75$ tahun. Diperkirakan penderita hipertensi di Indonesia mencapai 15 juta jiwa tetapi hanya $4 \%$ yang merupakan hipertensi terkontrol. Prevalensi $6-15 \%$ pada orang lanjut usia, 50\% tidak menyadari sebagai penderita hipertensi sehingga mereka cenderung menjadi hipertensi berat karena tidak menghindari dan tidak mengetahui faktor risikonya dan $90 \%$ merupakan hipertensi esensial.

Tujuan: Mengetahui pengaruh pemberian jus mentimun terhadap tekanan darah pada wanita menopause di wilayah kerja puskesmas baktijaya kota tangerang selatan tahun 2021 pada kelompok intervensi dan kelompok kontrol.

Metodologi: Peneliti menggunakan desain penelitian quasi-eksperimen dengan rancangan pre-test and with control. Sampel dalam penelitian berjumlah 36 orang yang terdiri dari 18 kelompok intervensi dan 18 kelompok kontrol. Teknik pengambilan sampel menggunakan purposive sampling. Instrumen penelitian terdiri dari pada lembar observasi keadaan tekanan darah pada penderita hipertensi sebelum diberikan jus mentimun dan perubahan tekanan darah pada wanita menopause yang mengalami hipertensi setelah diberikan jus mentimun.

Hasil Penelitian: Ada pengaruh pemberian jus mentimun terhadap penurunan tekanan darah pada kelompok intervensi dengan mean rank 13,72 dan pada kelompok kontrol dengan mean rank 23,28 . Dengan nilai $p$ value sebesar $0,005<0,05$. Ada pengaruh pemberian jus mentimun terhadap penurunan tekanan darah 
diastolik pada kelompok intervensi dengan mean rank 23,94 dan pada kelompok kontrol dengan mean rank 13,06. nilai $p$ value sebesar $0,001<0,05$. menopause.

Simpulan Pemberian jus mentimun dapat berpengaruh terhadap penurunan tekanan darah pada wanita

Saran pemberian jus mentimun pada wanita menopause atau masyarakat dapat diterapkan dan dikonsumsi secara rutin.

Kata Kunci : Wanita Menopause, Hipertensi, Mentimun

\section{PENDAHULUAN}

Wanita Menopause merupakan sebuah kata yang memiliki banyak arti atau makna yang terdiri dari kata menos dan pausos yang berasal dari bahasa yunani, yang digunakan untuk menjelaskan gambaran berhentinya haid atau mesntruasi. Hal ini merupakan akhir proses biologis dari siklus menstruasi, hormone yaitu penurunan produksi hormon estrogen yang dihasilkan oleh ovarium.Mulyani,(2017)

bertambahnya umur, hipertensi merupakan faktor risiko utama yang menyebabkan meningkatnya morbiditas dan mortalitas kardiovaskular pada wanita yang sudah mengalami menopause. .(Mulyani,2017)

Prevalensi hipertensi di Indonesia sebesar 45,9\% untuk umur 55-64 tahun, 57,6\% umur 65-74 tahun dan 63,8 \% umur > 75 tahun. Prevalensi hipertensi di Indonesia berdasarkan pengukuran tekanan darah pada umur $\geq 18$ tahun adalah sebesar $25,8 \%$. Prevalensi tertinggi di Banten $(30,9 \%)$, diikuti Kalimantan Selatan $(30,8$ $\%$ ), Kalimantan Timur (29,6\%). Kemenkes RI. (2018)

Di Indonesia mencapai $17-21 \%$ dari populasi penduduk kebanyakan tidak terdeteksi. Dari jumlah itu $60 \%$ penderita hipertensi berakhir pada stroke. Diperkirakan penderita hipertensi di Indonesia mencapai 15 juta jiwa tetapi hanya 4\% yang merupakan hipertensi terkontrol. Prevalensi 6-15\% pada orang lanjut usia, $50 \%$ tidak menyadari sebagai penderita hipertensi sehingga mereka cenderung menjadi hipertensi berat karena tidak menghindari dan tidak mengetahui faktor risikonya dan $90 \%$ merupaka hipertensi esensial. Hartono, (2018)

Salah satu bentuk pengobatan nonfarmakologis tidak menimbulkan efek samping bagi kesehatan wanita menopause dengan mengkonsumsi sayuran yang dapat mempengaruhi tekanan darah seperti dengan mengkonsumsi mentimun. Selain mengandung zat-zat yang bermanfaat bagi kesehatan, mentimun juga terbilang jauh lebih murah dan ekonomis jika dibandingkan dengan biaya pengobatan farmakologis. Wanita menopause hipertensi bisa melakukan terapi nutrisi dengan manajemen diet hipertensi. Contohnya dengan pembatasan konsumsi garam, mempertahankan asupan kalium, kalsium, dan magnesium serta membatasi asupan kalori jika berat badan meningkat. Selain itu terapi yang sering digunakan masyarakat adalah buah mentimun yang sangat baik di konsumsi untuk penderita hipertensi. Mentimun dikatakan makanan yang sehat untuk pembuluh darah dan jantung, dimana makanan tersebut mengandung kalium yang bekerja sebagai melebarkan pembuluh darah sehingga tekanan darah menurun. Mentimun juga mempunyai bersifat diuretik karena kandungan airnya yang tinggi sehingga membantu menurunkan tekanan darah dan dapat meningkatkan buang air kecil. Cerry, dkk. (2015)

Hal ini menjelaskan bahwa terapi jus mentimun cukup berperan dalam menurunkan tekanan darah pada penderita hipertensi. Kandungan mineral kalium, magnesium dan serat di dalam jus mentimun bermanfaat untuk menurunkan tekanan darah. Mineral magnesium juga berperan melancarkan aliran darah dan menenangkan saraf. Purba, S. (2019)

Berdasarkan hasil studi pendahuluan yang dilakukan di Puskesmas Baktijaya Kota Tangerang Selatan didapatkan data pada tahun 2020, 982 orang $(24,5 \%)$ yang melakukan pengobatan, sedangkan target penanganan hipertensi puskesmas Baktijaya (27,5\%). Selisih yang didapat dari target yaitu $(3 \%)$. Berdasarkan hasil informasi dari tenaga kesehatan di puskesmas baktijaya 15 wanita menopause yang memiliki hipertensi, $85 \%$ diantaranya menggunakan obat-obatan seperti Amlodipin, Captopril, Nifedipin sesuai dengan yang di anjurkan puskesmas atau tenaga kesehatan.

Berdasarkan latar belakang diatas, maka peneliti melakukan penelitian dengan judul " Pengaruh Pemberian Jus Mentimun Terhadap Tekanan Darah Pada Wanita Menopause di Wilayah Kerja Puskesmas Baktijaya Kota Tangerang Selatan Tahun 2021". 


\section{JKM (Jurnal Kebidanan Malahayati),Vol 7,No.4.Oktober 2021, \\ ISSN (Print) 2476-8944 ISSN (Online) 2579-762X, Hal 697-703}

\section{METODE PENELITIAN}

Penelitian ini menggunakan desain penelitian quasi-eksperimen dengan rancangan pretest and with control yang berupaya mengungkapkan hubungan sebab akibat dimana rancangan ini menggunakan kelompok intervensi dan kontrol untuk mengidentifikasi pengaruh pemberian jus mentimun terhadap tekanan darah pada wanita menopause.

Populasi dalam penelitian ini adalah seluruh wanita menopause yang mengalami Hipertensi yang berada di Wilayah Kerja Puskesmas Baktijaya Kota Tangerang Selatan Tahun 2021 yaitu sebanyak 36 orang. Metode pengambilan sampel dalam penelitian ini menggunakan teknik total sampling. Total sampling adalah teknik pengambilan sampel dengan cara mengambil semua anggota populasi menjadi sampel. Didapatkan jumlah sampel yaitu 36 wanita menopause yang mempunyai hipertensi dengan memenuhi kriteria inklusi menjadi 18 orang sebagai kelompok intervensi (Pasien yang diberikan jus mentimun) dan kriteria eksklusi 18 orang sebagai kelompok kontrol (yang tidak dikasih jus mentimun sebagai pembanding).
Melakukan pemeriksaan tekanan darah pada wanita menopause dengan menggunakan sfigmomano meter dan stetoskop. Tekanan darah > $140 \mathrm{mmHg}$ dan tanpa komplikasi untuk dijadikan sampel penelitian. Responden dilakukan pemberian jus mentimun dua kali sehari, pagi pukul 07.00 WIB. Dan sore 17.00 WIB, sebanyak 250 cc selama 7 hari. Pemeriksaan tekanan darah dilakukan pada hari pertama, hari ke empat, dan hari ke delapan untuk melihat hasil setelah diberikan jus mentimun. Untuk hari kedua, ketiga, kelima, keenam dan ketujuh dilakukan pemantauan bukti dokumentasi melalui WhatsApp grup.

Instrumen yang digunakan dalam penelitian adalah lembar observasi yang digunakan dalam mencatat nama, umur, responden serta hasil pemeriksaan tekanan darah sebelum dan sesudah meminum jus mentimun.

Analisa Univariat adalah untuk mengetahui nilai frekuensi tekanan darah pada wanita menopause penderita hipertensi pre test dan post test. Analisis bivariate dilakukan untuk mengetahui pengaruh antara jus mentimun dengan tekanan darah pada wanita menopause penderita hipertensi menggunakan uji Wilcoxon Signed Ranks Test.

\section{HASIL DAN PEMBAHASAN}

Tabel 1.

Uji Normalitas Terhadap Tekanan Darah Sistolik dan Diastolik

\begin{tabular}{lccc}
\hline \multicolumn{1}{c}{ Tekanan darah } & N & Kolmogorov Smirnov & Shapiro-Wilk \\
\hline $\begin{array}{l}\text { Sistolik } \\
\text { Kelompok Intervensi }\end{array}$ & & & \\
$\begin{array}{l}\text { Pre-test } \\
\text { Post-test }\end{array}$ & 18 & 0.007 & 0,077 \\
$\begin{array}{l}\text { Kelompok Kontrol } \\
\text { Pre-test }\end{array}$ & 18 & 0.018 & 0,010 \\
$\begin{array}{l}\text { Post-test } \\
\text { Diastolik }\end{array}$ & 18 & 0.023 & 0,061 \\
Kelompok Intervensi & 18 & 0.017 & 0,030 \\
$\begin{array}{l}\text { Pre-test } \\
\text { Post-test }\end{array}$ & 18 & & \\
Kelompok Kontrol & 18 & 0.022 & \\
Pre-test & & 0.059 & 0,040 \\
Post-test & 18 & & \\
\hline
\end{tabular}

Berdasarkan tabel diatas menujukan hasil analisis pada data sistolik pre test kelompok intervensi nilai sig. $0,077<0,05$ dan post test kelompok intervensi nilai sig. $0,010<0,05$ sedangkan pre test kelompok kontrol nilai sig 0,061 $>0,05$ dan post test kelompok kontrol nilai sig 0,030 $>0,05$. Sementara analisis pada data diastolik pre test kelompok intervensi nilai sig. 0,040<0,05 dan post test kelompok intervensi nilai sig. 0,036 <0,05 sedangkan pre test kelompok kontrol nilai sig 0,014 $>0,05$ dan post test kelompok kontrol nilai sig 0,000 $<0,05$. Hal ini menunjukan bahwa data pada hasil pada kelompok kontrol tersebut tidak berdistribusi normal, sehingga peneliti melakukan analisis uji statistik dengan wilcoxon signed rank. 
Fika Kusmawati, Sri Dinengsih, Risza Choirunisa

Tabel 2.

Perbedaan Tekanan Darah Sistolik Pada Wanita Menopause Pada Kelompok Intervensi dan Kontrol

\begin{tabular}{lccccc}
\hline Tekanan darah Sistolik & N & Mean Rank & Sum of Ranks & Z & p-value \\
\hline Posttest Intervensi & 18 & 13,72 & 247,00 & \multirow{2}{*}{$-2,801$} & \multirow{2}{*}{0.005} \\
Posttest Kontrol & 18 & 23,28 & 419,00 & & \\
\hline
\end{tabular}

Berdasarkan hasil tabel diatas menunjukan bahwa terdapat perbedaan penurunan tekanan darah pada kelompok intervensi dengan mean rank 13,72 dan pada kelompok kontrol dengan mean rank 23,28. Berdasarkan nilai $p$ value sebesar 0,005
$<0,05$ maka dapat disimpulkan bahwa hipotesis diterima. Dengan demikian dapat dikatakan bahwa ada pengaruh pemberian jus mentimun terhadap penurunan tekanan darah.

Tabel 3.

Perbedaan Tekanan Darah Diastolik Pada Wanita Menopause Pada Kelompok Intervensi dan Kontrol

\begin{tabular}{lccccc}
\hline Tekanan darah diastolic & N & Mean Rank & Sum of Ranks & Z & p-value \\
\hline Posttest Intervensi & 18 & 23,94 & 431,00 & $-3,278$ & \multirow{2}{*}{0.001} \\
Posttest Kontrol & 18 & 13,06 & 235,00 & & \\
\hline
\end{tabular}

Hasil tabel menunjukan bahwa terdapat perbedaan penurunan tekanan darah diastolik Berdasarkan output Test Statistik diketahui bahwa nilai Asymp. Sig. (2-tailed) sebesar 0,001 $<0,05$ maka dapat bahwa hipotesis diterima. Dengan demikian dapat dikatakan bahwa ada pengaruh pemberian jus mentimun terhadap penurunan tekanan darah.

\section{PEMBAHASAN}

Rata-rata tekanan darah pada wanita menopause sebelum dan sesudah pada kelompok intervensi

Berdasarkan hasil penelitian pada kelompok intervensi bahwa rata-rata tekanan darah sistolik pada penderita hipertensi sebelum mengkonsumsi jus mentimun adalah $164,44 \mathrm{mmHg}$ dan sesudah mengkonsumsi jus mentimun adalah $125,00 \mathrm{mmHg}$, serta diketahui rata-rata penurunan tekanan darah sistolik sebelum dan sesudah mengkonsumsi jus mentimun adalah $39,444 \mathrm{mmHg}$. Sedangkan ratarata tekanan darah diastolik pada penderita hipertensi sebelum mengkonsumsi jus mentimun adalah $92,78 \mathrm{mmHg}$ dan sesudah mengkonsumsi jus mentimun adalah $83,33 \mathrm{mmHg}$, serta diketahui rata-rata penurunan tekanan darah diastolik sebelum dan sesudah mengkonsumsi jus mentimun adalah $9,444 \mathrm{mmHg}$.

Diketahui bahwa Buah mentimun mampu membantu menurunkan tekanan darah karena kandungan mentimun diantaranya kalium, magnesium, dan fosfor efektif mengobati hipertensi. Kalium yaitu elektrolit intraseluler yang utama, $98 \%$ kalium tubuh berada di dalam sel, $2 \%$ sisanya di luar sel untuk fungsi neuromuskuler, kalium memperngaruhi aktifitas baik otot skeletal maupun otot jantung. Mentimun juga mempunyai sifat diuretik yang terdiri dari $90 \%$ air, sehingga mampu mengeluarkan kandungan garam di dalam tubuh. Mineral yang kaya dalam buah mentimun mampu mengikat garam dan dikeluarkan lewat urin. Lebalado. (2014)

Pengaruh kandungan jus mentimun terhadap tekanan darah terihat jelas dalam peranan kalium, kalsium. Kalium berperan dalam menjaga kestabilan elektrolit tubuh melalui pompa kaliumnatrium. Kurangnya kadar kalium dalam darah akan mengganggu rasio kalium-natrium sehingga kadar natrium akan meningkat. Hal ini dapat menyebabkan pengendapan kalsium pada persendian dan tulang belakang yang meningkatkan beban kerja jantung dan pengumpalan natrium dalam pembuluh darah. Kharisna, D. (2019)

Menurut asumsi peneliti adanya perbedaan rata-rata tekanan darah sebelum dan sesudah pada kelompok intervensi karena pada jus mentimun terdapat kandungan mineral kalium yang merupakan elektrolit intraseluler yang utama. Kalium mempengaruhi aktivitas baik otot skelet maupun otot jantung maka dari meminum jus mentimun dapat menurunkan tekanan darah dan sangat baik untuk penderita hipertensi, selain dari jus mentimun faktor yang mempengaruhi yaitu dari pola hidup dengan diit garam dan rutin berolahraga. 


\section{JKM (Jurnal Kebidanan Malahayati),Vol 7,No.4.Oktober 2021, \\ ISSN (Print) 2476-8944 ISSN (Online) 2579-762X, Hal 697-703}

\section{Rata-rata tekanan darah pada wanita menopause sebelum dan sesudah pada kelompok kontrol}

Berdasarkan hasil penelitian pada kelompok kontrol bahwa rata-rata tekanan darah sistolik pada penderita hipertensi sebelum mengkonsumsi jus mentimun adalah $160,00 \mathrm{mmHg}$ dan sesudah mengkonsumsi jus mentimun adalah $138,33 \mathrm{mmHg}$, serta diketahui rata-rata penurunan tekanan darah sistolik sebelum dan sesudah mengkonsumsi jus mentimun adalah 21,667 mmHg. Sedangkan ratarata tekanan darah diastolik pada penderita hipertensi sebelum mengkonsumsi jus mentimun adalah $84,44 \mathrm{mmHg}$ dan sesudah mengkonsumsi jus mentimun adalah $78,33 \mathrm{mmHg}$, serta diketahui rata-rata penurunan tekanan darah diastolik sebelum dan sesudah mengkonsumsi jus mentimun adalah $6,111 \mathrm{mmHg}$. Hasil penelitian menunjukan penurunan tekanan darah pada kelompok kontrol. Hal tersebut dikarenakan wanita menopause pada kelompok control tetap mengkonsumsi obat hipertensi Ampodipin $10 \mathrm{mg} \mathrm{1 \times 1} \mathrm{(Malam)} \mathrm{tetapi}$ penurunan tekanan darah tidak sesignifikan dengan wanita menopause yang mengkonsumsi jus mentimun.

Efektifitas pemberian obat anti hipertensi dengan pemberian jus mentimun terhadap penurunan tekanan darah lansia dengan riwayat hipertensi dikota padang, pemberian obat anti hipertensi pada penelitian ini yaitu selama 7 hari, sebelum pemberian pemberian obat anti hipertensi pada penelitian ini melakukan pretest. Dengan hasil ditemukan rata-rata frekuensi tekanan darah sistolik sebelum diberikan pemberian obat anti hipertensi adalah 174.57 dengan standar deviasi 11.69 frekunsi nilai terendah 160 dan tertinggi 200 dan Dan rata-rata frekuensi tekanan darah diastolik sebelum diberikan pemberian obat anti hipertensi adalah 96.79 dengan standar deviasi 5.3 nilai tertinggi 105 dan terendah 85 . Rata-rata frekuensi sistolik setelah diberikan jus mentimun adalah 142,07 dengan standar deviasi 10,35 dengan nilai terendah 130 dan tertinggi 170 dan rata-rata frekuensi diastolik setelah diberikan pemberian obat anti hipertensi adalah 90,14 dengan standar deviasi 5.97 dengan nilai terendah 80 dan tertinggi 100 . Soemantri, U. W. (2020)

Sebelum diberikan pemberian obat anti hipertensi ditemukan rata-rata tekanan darah penderita hipertensi 174.57 , terlihat bahwa tekanan darah masih tinggi hal ini disebabkan karena faktor keturunan dan obesitas, secara teori penyebab hipertensi adalah faktor keturunan, perokok, obesitas, alkoholisme, stress dan konsumsi garam. Selain itu masih tingginya tekanan darah penderita hipertensi karena tidak berfungsinya asam amino sitrulin untuk memproduksi asam amino arginin, tidak terbentuknya asam amino arginin sehingga tidak dapat digunakan oleh sek-sel pelapis pembuluh darah untuk membuat nitrat oksida sehingga tidak dapat berfungsi nitrat oksida untuk melemaskan pembuluh darah yang membuat tekanan darah meningkat. Tjiptaningrum, A., Erhadestria, S. (2016)

Menurut asumsi peneliti adanya perbedaan rata-rata tekanan darah sebelum dan sesudah pada kelompok kontrol karena pengunaan obat anti bergolongan Calcium Channel Blocker (CCB) yaitu amplodipine. Cara kerja obat tersebut membantu kalsium masuk ke sel otot jantung dan pembuluh darah, maka hal tersebut membuat kerja jantung menjadi lebih ringan dan pembuluh darah menjadi lebih rileks hasilnya tekanan darah akan menurun, selain faktor dari mekanisme kerja pada obat difaktor juga oleh kepatuhan mengongsumsi obat hipertensi dalam menjaga tekanan darah pada wanita menopouse penderita agar menurunkan tekanan darah yang tinggi dan tetap dalam batas normal.

\section{Pengaruh pemberian mentimun terhadap tekanan darah pada wanita menopause}

Berdasarkan hasil penelitian pada kelompok intervensi bahwa penurunan tekanan darah sistolik sebelum dan sesudah mengkonsumsi jus mentimun adalah $39,444 \mathrm{mmHg}$ dan penurunan tekanan darah diastolik sebelum dan sesudah mengkonsumsi jus mentimun adalah $9,444 \mathrm{mmHg}$. Sedangkan pada kelompok kontrol penurunan tekanan darah sistolik sebelum dan sesudah mengkonsumsi jus mentimun adalah $21,667 \mathrm{mmHg}$ dan penurunan tekanan darah diastolik sebelum dan sesudah mengkonsumsi jus mentimun adalah $6,111 \mathrm{mmHg}$.

Penurunan tekanan darah terjadi karena mentimun mempunyai kandungan kalium menyebabkan penghambatan pada Renin Angiotensin System juga menyebabkan terjadinya penurunan sekresi aldosteron, sehingga terjadi penurunan reabsorpsi natrium dan air di tubulus ginjal. Akibat dari mekanisme tersebut, maka terjadi peningkatan diuresis yang menyebabkan berkurangnya volume darah, sehingga tekanan darah pun menjadi turun. Selain itu, kalium juga akan menyebabkan terjadinya vasodilatasi pembuluh darah perifer, akibatnya terjadi penurunan resistensi perifer, dan tekanan darah juga menjadi turun. Hal tersebut tejadi karena kandungan didalam mentimun yaitu potassium, magnesium, dan fosfor pada mentimun yang 
berkhasiat menurunkan tekanan darah tinggi. Mentimun juga bermanfaat sebagai detoksifikasi karena kandungan air sangat tinggi hingga 90\% membuat mentimun memiliki efek diuretic. Mineral yang kaya dalam mentimun memang mampu mengikat garam dan dikeluarkan melalui urin. Tukan, R. A. (2018)

Konsumsi kalium dalam jumlah yang tinggi dapat melindungi individu dari hipertensi. Fungsi dari kalium adalah bersama natrium, kalium memegang peranan dalam pemeliharaan keseimbangan cairan dan elektrolit serta keseimbangan asam basa. Bersama kalsium, kalium berperan dalam transmisi saraf dan relaksasi otot. Di dalam sel, kalium berfungsi sebagai katalisator dalam banyak reaksi biologik, terutama dalam metabolisme energi dan sintesis glikogen dan protein. Kalium berperan dalam pertumbuhan sel. Taraf kalium dalam otot berhubungan dengan masa otot dan simpangan glikogen, oleh karena itu bila otot berada dalam pembentukan dibutuhkan kalium dalam jumlah cukup. Tekanan darah normal memerlukan perbandingan antara natrium dan kalium yang sesuai di dalam tubuh. Perkiraan kebutuhan kalium di dalam tubuh, karena merupakan bagian esensial semua sel hidup, kalium banyak terdapat dalam bahan makanan, salah satunya adalah mentimun. Kebutuhan minimum akan kalium sebanyak $2000 \mathrm{mg}$ sehari. Pemenuhan kalium kurang dari minimum maka jantung akan berdebar-debar detaknya dan menurunkan kemampuan untuk memompa darah. Asupan kalium yang meningkat akan menurunkan tekanan darah sistolik dan diastolic. Lovinda, Putri. L. (2014)

Hal ini berarti menunjukkan bahwa kandungan mentimun yang dikonsumsi dapat mengurangi risiko terkena hipertensi dengan membantu mengurangi ketegangan otot dan emosional responden. Hasil-hasil penelitian ini menunjukkan bahwa mengkonsumsi jus mentimun berpengaruh atau memiliki efek yang yang positif terhadap tekanan darah.

Menurut asumsi peneliti adanya pengaruh terapi non farmakologi pemberian jus mentimun terhadap hipertensi pada wanita menopause karena jus mentimun merupakan salah satu yang mengandung asam amino sitrulin, asam amino arginine, nitrat oksida kalium dan air cukup tinggi. Pada asam amino arginin digunakan oleh sel-sel pelapis pembuluh darah untuk membuat nitrat oksida yang berfungsi untuk meringkan kerja jantung dan pembuluh darah menjadi rileks sehingga dapat menurunkan tekanan darah.

\section{SIMPULAN}

Berdasarkan hasil penelitian tentang pengaruh pemberian jus mentimun terhadap tekanan darah pada wanita menopause di wilayah kerja puskesmas baktijaya kota tangerang selatan tahun 2021, dapat disimpulkan kelompok intervensi rata-rata tekanan darah sistolik sebelum mengkonsumsi jus mentimun adalah $164,44 \mathrm{mmHg}$, dan sesudah mengkonsumsi jus mentimun adalah $125,00 \mathrm{mmHg}$. Kelompok intervensi Rata-rata tekanan darah diastolik sebelum mengkonsumsi jus mentimun adalah $92,78 \mathrm{mmHg}$ dan sesudah mengkonsumsi jus mentimun adalah $83,33 \mathrm{mmHg}$. kelompok kontrol Rata-rata tekanan darah sistolik sebelum mengkonsumsi jus mentimun adalah $160,00 \mathrm{mmHg}$ dan sesudah mengkonsumsi jus mentimun adalah 138,33 mmHg. kelompok kontrol Rata-rata tekanan darah sistolik sebelum mengkonsumsi jus mentimun adalah $84,44 \mathrm{mmHg}$, dan sesudah mengkonsumsi jus mentimun adalah $78,33 \mathrm{mmHg}$. Maka pemberian jus mentimun dapat berpengaruh terhadap penurunan tekanan darah pada wanita menopause yang mengalami hipertensi.

\section{SARAN}

Memberikan pendidikan kesehatan mengenai pencegahan hipertensi untuk menjaga kestabilan tekanan darah, serta dapat memberikan pendidikan kesehatan tentang terapi herbal khususnya konsumsi jus mentimun sebagai salah satu alternatif pengobatan non-medis bagi penderita hipertensi yang berkunjung ke wilayah kerja puskesmas baktijaya.

Diharapkan peneliti lainnya dapat mempersiapkan pengetahuan yang memadai tentang penyakit hipertensi dan obat tradisional, sehingga saat peneliti terjun di masyarakat mereka mampu menjadi narasumber dan berperan aktif dalam masyarakat khususnya mengenai penyakit hipertensi dan penanganannya.

\section{DAFTAR PUSTAKA}

Mulyani, N. (2017). Menopause Akhir Siklus Menstruasi pada Wanita di Usia Pertengahan. Kedua. Yogyakarta: Nuha Medika.

Kemenkes RI. (2018). Manfaat aktivitas fisik Direktorat P2PTM. Retrieved from http : // www. $\quad$ p2ptm. kemkes.go.id/infographicp2ptm/hipertensipenyakit-jantung-danpembuluhdarah/manfaat-aktivitas-fisik

Hartono, (2018). Hipertensi The Silent Killer. Perhimpunan Hipertensi Indonesia. Jakarta. 
Cerry, dkk. (2015).Pengaruh pemberian jus mentimun terhadap tekanan darah pada penderita hipertensidi desa tolombukankec.
Pasan
Kab.
Minahasa

tenggara.(https://ejournal.unsrat.ac.id/index. php/jkp/article/view/8088, diakses 26 Juli 2021)

Purba, S. (2019). Pengaruh Pemberian Jus Mentimun (Cucumis Sativus Linn) Terhadap Penurunan Tekanan Darah Pada Pasien Hipertensi di Desa Sindang Barang Kota Bogor. Jurnal Ilmiah Wijaya, Volume 11 Nomor 2.

Lebalado. (2014). Pengaruh Pemberian Jus Mentimun (Cucumis sativus L.) TerhadapTekanan Darah Sistolik Dan Diastolik Pada Penderita Hipertensi. Skripsi Universitas Diponegoro. Semarang.

Kharisna, D. (2019). Efektifitas Konsumsi Jus Mentimun terhadap Penurunan Tekanan
Darah pada Pasien Hipertensi. (diakses pada 22 Juli 2021)

Soemantri, U. W. (2020). Efektivitas Jus Mentimun Terhadap Penurunan Tekanan Darah pada Lansia Penderita Hipertensi di Desa Kondangjaya Pandeglang-Banten. Abdidas, Vol 1 No 2. $57-63$.

Tjiptaningrum, A., Erhadestria, S. (2016). Manfaat Jus Mentimun ( Curcumis Sativus L.) Sebagai Terapi Untuk Hipertensi. Majority, Vol. 5 No. 1.

Tukan, R. A. (2018). Efektifitas Jus Mentimun Dalam Menurunkan Tekanan Darah Pada Pasien Hipertensi. Journal of Borneo Holistic Health, Volume 1 No. 1. P ISSN 2621-9530

Lovinda, Putri. L. (2014). Jurnal Pengaruh pemberian jus mentimun (cucumis sativus L.) terhadap tekanan darah sistolik dan diastolic pada penderita hipertensi. 